https://doi.org/10.18778/7525-969-8.32

\title{
Patrycja Sokotowska
}

\section{Pięć lat niepodległości Kosowa. Wyzwania dla najmłodszego państwa w Europie}

Piąta rocznica uzyskania niepodległości przez Kosowo to dobry moment do podsumowania i analizy sukcesów i porażek najmłodszego państwa w Europie oraz zwrócenia szczególnej uwagi na procesy, które w tym regionie zachodzą ${ }^{2}$. Ostatnie lata pokazały bowiem, że Kosowo nadal boryka się z szeregiem problemów natury politycznej, gospodarczej oraz społecznej. Najistotniejszym wyzwaniem jest brak stabilności politycznej, praworządności, a zwłaszcza efektywnych instytucji państwowych (obecnie uzależnionych od pomocy międzynarodowej). Ciagłe kryzysy polityczne i podziały wewnętrzne, fałszerstwa wyborcze, do których doszło w 2010 r., jak też brak implementacji uchwalonych ustaw utrudniają sprawne rządzenie. Również niejasna kwestia statusu Kosowa, brak kontroli nad całym terytorium państwa uniemożliwiają mu funkcjonowanie jako pełnoprawnemu aktorowi stosunków międzynarodowych. Sytuacji nie ułatwia zbytnio fakt, iz Kosowo uznane jest przez 90 państw świata. Nadal bowiem nie jest członkiem Organizacji Narodów Zjednoczonych (ONZ) i innych instytucji międzynarodowych z wyjątkiem Banku Światowego oraz Międzynarodowego Funduszu Walutowego. Również Unia Europejska (UE) podzielona jest w sprawie niepodległości tego kraju, a Słowacja, Rumunia, Grecja, Hiszpania i Cypr wciąż odmawiają jego uznania. Bezpieczeństwo państwa, kwestia ochrony granic, mierne rezultaty walki ze zorganizowana przestępczością oraz korupcją to kolejne problemy, z którymi boryka się Kosowo.

${ }^{1}$ Autorka jest doradcą sekretarza stanu w Biurze Pełnomocnika Prezesa Rady Ministrów ds. Dialogu Międzynarodowego w Kancelarii Prezesa Rady Ministrów (KPRM). Tezy i opinie zawarte w tekście nie są oficjalnym stanowiskiem KPRM i wyrażają jedynie opinie autorki.

${ }^{2}$ Artykuł powstał w ramach projektu pt. Kosowo jako suwerenne państwo. Teoria i praktyka, który został sfinansowany ze środków Narodowego Centrum Nauki. 


\section{Relacje kosowsko-serbskie i problem północy a integralność terytorialna Republiki Kosowa}

Od ogłoszenia niepodległości przez Kosowo w 2008 r. Belgrad sprzeciwia się jego uznaniu i faktycznie sprawuje pełną kontrolę nad jego północną częścią zamieszkiwana głównie przez ludność serbska. Jednocześnie wspiera też Serbów mieszkających w enklawach na południe od rzeki Ibar. Pod wpływem nacisków ze strony Brukseli oraz w celu wzmocnienia szans na uzyskanie statusu kandydata do UE, Belgrad rozpoczął w marcu 2011 r., pod auspicjami Unii, negocjacje z Prisztina w sprawie tzw. kwestii technicznych obejmujacych takie obszary, jak: wzajemne uznawanie dokumentów, ochrona granic, wymiana handlowa, transport, telekomunikacja, energia elektryczna, gospodarka wodna, ochrona dziedzictwa kulturowego i historycznego oraz walka ze zorganizowaną przestępczością ${ }^{3}$. Mimo osiagnięcia porozumienia w kwestii swobodnego przepływu osób, przekazania Prisztinie kopii rejestrów cywilnych oraz katastru, uznania pieczęci kosowskiego urzędu celnego, jak też porozumienia w sprawie współpracy i reprezentacji regionalnej, a także Zintegrowanego Systemu Zarządzania Granicami ${ }^{4}$, istnieją trudności związane z implementacją tych dokumentów. Dokumenty te nigdy bowiem nie zostały podpisane przez przedstawicieli Serbii. Belgrad w tym wypadku decyduje się jedynie na ich sygnowanie, aby uniknać zarzutu, że złożenie podpisu mogłoby być zrozumiane jako uznanie niepodległości Kosowa. Porozumienia po obu stronach nie ułatwiała sytuacja polityczna w Serbii oraz kryzys rządowy i konstytucyjny w Kosowie zapoczątkowany dymisją prezydenta Kosowa Fatimira Sejdu.

W dniu 27 września 2010 r. prezydent Sejdu ustapił z urzędu po orzeczeniu Trybunału Konstytucyjnego uznającym, iż łączenie funkcji głowy państwa ze stanowiskiem przewodniczacego partii jest niezgodne z ustawą zasadnicza. Podanie się go do dymisji doprowadziło w dniu 16 października 2010 r. do wyjścia z koalicji rządzącej Demokratycznej Ligi Kosowa (LDK), a następnie przyjęcia (2 listopada 2010 r.) wotum nieufności dla rządu Hashima Thaçiego. W konsekwencji odejście F. Sejdu doprowadziło do kryzysu politycznego i przeprowadzenia przedterminowych wyborów, które odbyły się 12 grudnia $2010 \mathrm{r}$. W efekcie powstał słaby rząd kierowany przez premiera Thaçiego i jego partię Demokratyczną Partię Kosowa (PDK) w koalicji z Sojuszem na rzecz Nowego Kosowa (Aleanca Kosova e Re, AKR), który zdobył 7,1\% głosów, i partiami mniejszości narodowych. Do parlamentu dostała się również kierowana przez Albina Kurtiego ${ }^{5}$, krytyczna wobec rządu oraz sceptyczna w odniesieniu do zasadności

${ }^{3}$ Serbia i Kosowo rozmawiaja, „Gazeta Wyborcza”, 9 III 2011, http://wyborcza. pl/1,76842,9221475,Serbia_i_Kosowo_rozmawiaja.html (dostęp 20 X 2012).

${ }^{4}$ Zob. The agreements reached in Belgrade-Pristina dialogue with EU mediation, http://www.srbija.gov.rs/kosovo-metohija/index.php?id=82315 (dostęp 20 X 2012).

${ }_{5}^{5}$ Zob. A. Skieterska, Polityczna rewolucja w Kosowie, 13 XII 2010, http://wyborcza. 
prowadzenia negocjacji z Serbia, nowa partia Vetevendosje (Samostanowienie), osiagając $12,2 \%$ głosów i stając się trzecią siłą w parlamencie po LDK i po PDK ${ }^{6}$. Brak zdecydowanego zwycięzcy wyborów, ograniczone możliwości koalicyjne PDK, zbyt mała większość parlamentarna oraz kolejny kryzys konstytucyjny związany z wyborem Behgjeta Pacolliego na prezydenta Kosowa ${ }^{7}$ doprowadziły do ciagłego napięcia politycznego oraz kwestionowania przez opozycję sensu podjęcia negocjacji z Belgradem. Niezadowolenie opozycji osiagnęło apogeum w dniu 22 października 2012 r., kiedy to podczas demonstracji kierowanej przez ruch Vetevendosje doszło do zamieszek, w których 23 osoby zostały ranne, a 63 zatrzymano. Powodem manifestacji było rozpoczęcie przez premiera Thaçiego negocjacji z nowym premierem Serbii Ivica Dačiciem, które odbyły się 19 października 2012 r. Tuż przed rozpoczęciem rozmów parlament Kosowa przyjął rezolucję wzywającą do normalizacji stosunków z Serbią przy poszanowaniu „suwerenności Kosowa, jego integralności terytorialnej i porządku konstytucyjnego". Od czasu otwarcia tzw. dialogu technicznego w marcu $2011 \mathrm{r}$. było to pierwsze na tak wysokim szczeblu spotkanie przedstawicieli obu państw ${ }^{8}$.

Również sytuacja polityczna w Serbii oraz dążenie od 2009 r. do uzyskania statusu kandydata do UE powodowały, że Belgrad unikał konfrontacji z Prisztiną przystając na szereg ustępstw i doprowadzając tym samym do coraz większego niezadowolenia Serbów w północnym Kosowie. Rząd Serbii świadomy zbliżających się wyborów parlamentarnych, prezydenckich i lokalnych stosował podwójną strategię, która oprócz ustępstw na rzecz Prisztiny przejawiała się w dalszym wspieraniu Serbów i finansowaniu ich instytucji w Kosowie. Balansowanie pomiędzy oczekiwaniami społeczeństwa a żądaniami UE były negatywnie przyjmowane przez ludność Serbii, okazująca zrozumienie dla rodaków w północnym Kosowie ${ }^{9}$. Ostatecznie wybory parlamentarne i prezydenckie

pl/1,76842,8812437,Polityczna_rewolucja_w_Kosowie.html (dostęp 10 X 2012).

${ }^{6}$ M. Szpala, Wybory w Kosowie - niepewna stabilizacja, 15 XII 2010, http://www. osw.waw.pl/pl/publikacje/best/2010-12-15/wybory-w-kosowie-niepewna-stabilizacja (dostęp 15 XII 2012).

7 Trybunał Konstytucyjny uznał wówczas, że wybór nowego prezydenta przez parlament jest niezgodny z konstytucja, gdyż w wyborach powinno wziać udział przynajmniej dwóch kandydatów, a nie jeden, tak jak to było w przypadku B. Pacolliego. Dodatkowo za niezgodny z konstytucją uznano fakt, że w głosowaniu wzięło udział mniej niż obowiązkowe minimum $2 / 3$ parlamentarzystów. Obecnych było wówczas tylko 67 ze 120 posłów - zob. Prezydent Kosowa podat się do dymisji, 30 III 2011, http://wyborcza. pl/1,76842,9349213,Prezydent_Kosowa_podal_sie_do_dymisji.html (dostęp 10 X 2012).

8 Kosowo. Premier Thaci krytykuje opozycje za stanowisko wobec Serbii, 23 X 2012, http://wiadomosci.gazeta.pl/wiadomosci/1,114877,12723322,Kosowo_Premier_Thaci_ krytykuje_opozycje_za_stanowisko.html (dostęp 23 X 2012).

${ }_{9}$ M. Szpala, Eskalacja napięcia na granicy serbsko-kosowskiej: kryzys zażegnany, problem pozostaje, 10 VIII 2011, http://www.osw.waw.pl/pl/publikacje/best/2011-08-10/ eskalacja-napiecia-na-granicy-serbskokosowskiej-kryzys-zazegnany-problem (dostęp 10 X 2012). 
z 6 maja 2012 r. zmieniły serbską scenę polityczna. Prezydentem został Tomislav Nikolić z Serbskiej Partii Postępu (Srpska napredna stranka, SNS), wygrywając z dotychczasową głowa państwa Borisem Tadiciem. Parlamentarna wygrana prawicowej SNS, dotychczasowej największej partii opozycyjnej, z wynikiem $24 \%$ głosów $^{10}$ oraz stworzenie nowej koalicji z postmiloševiciowską Serbską Partią Socjalistyczną i liberalną partią Zjednoczone Regiony Serbii zmniejszyła szanse na pogłębienie porozumienia kosowsko-serbskiego. Co prawda nowy rząd w Belgradzie coraz częściej akcentuje potrzebę rozmów z Kosowem, ale tylko na płaszczyźnie technicznej, dotyczącej kwestii energetycznych i telekomunikacyjnych, nie zaś politycznych. Stanowisko to jest odmienne od planów wcześniejszej koalicji, która gotowa była podjać tzw. dialog polityczny, obejmujący zagadnienia północy Kosowa i nadania mu specjalnego statusu. Nowo wybrany dyrektor Biura Rządowego ds. Kosowa Aleksandar Vulin podkreślił też, że Serbia jest gotowa do rozmów, ale nie zrzeknie się Kosowa i Metochii. Jego zdaniem nowy rząd, w przeciwieństwie do poprzedniego, ma bardzo dobre relacje z Serbami z Kosowa i jest w ciagłym kontakcie z przedstawicielami tego regionu. Vulin zapewnił, że nie będzie żadnych negocjacji ani żadnej platformy temu służącej, jeśli w owych kwestiach nie wypowiedzą się kosowscy Serbowie ${ }^{11}$.

Stosunki serbsko-kosowskie zaostrzyły się w dniu 20 lipca 2011 r., kiedy rząd Kosowa podją decyzję o wprowadzeniu zakazu importu serbskich produktów i nałożeniu 10-procentowego cła na wyroby pochodzące z Bośni i Hercegowiny. Decyzja Prisztiny została podjęta w związku z odwołaniem rundy rozmów serbsko-kosowskich w sprawie swobodnego przepływu towarów. Od ogłoszenia niepodległości zarówno Belgrad, jak i Sarajewo blokowały import oraz tranzyt kosowskich produktów nie uznając dokumentów celnych wydanych przez Prisztinę ${ }^{12}$. W celu wyegzekwowania przestrzegania zakazu na przejściach granicznych, znajdujących się na obszarze zamieszkanym przez mniejszość serbska, rząd kosowski skierował na przejścia na północy kraju (Jarinje, Brnjak) funkcjonariuszy służby celnej i specjalnych jednostek policji ${ }^{13}-$ tzw. Regionalnych Operacyjnych Jednostek Wsparcia (Regional Operational Support Unit, ROSU), które są odpowiednikiem oddziałów prewencji. Akcja Prisztiny doprowadziła do protestów ludności serbskiej na północy Kosowa, blokady dróg, budowania

10 Główna partia z koalicji rządowej - centrowa Partia Demokratyczna (DS) zdobyła 22\% głosów. Natomiast na drugiego koalicjanta, lewicową Socjalistyczną Partię Serbii (SPS), głosowało 14,5\% wyborców. T. Żornaczuk, Serbia przed druga turq wyborów prezydenckich i powołaniem nowego rzqdu, ,Biuletyn” [PISM], 18 V 2012, nr 50/915, http:// www.pism.pl/files/?id_plik=10481 (dostęp 10 X 2012).

11 Vulin: Serbia ready for the dialogue, 2 X 2012, http://www.m-magazine.org/en/ Region/Vulin-Serbia-ready-for-the-dialogue-3262 (dostęp 20 X 2012).

12 M. Szpala, Kosowo wprowadza embargo na serbskie produkty, 27 VII 2011, http://www.osw.waw.pl/pl/publikacje/best/2011-07-27/kosowo-wprowadza-embargo-naserbskie-produkty (dostęp 23 X 2012).

${ }^{13}$ M. Szpala, Eskalacja napięcia... 
barykad oraz spalenia przejścia granicznego w Jarinje. W konsekwencji posterunki graniczne zostały opuszczone przez specjalne oddziały kosowskiej policji ROSU, a kontrolę nad nimi przejęli żołnierze sił KFOR ${ }^{14}$. Tym samym rozmowy dotyczace porozumienia o uznaniu pieczęci kosowskiego urzędu celnego i swobodnego obrotu towarami z Serbią w ramach dialogu technicznego, zakończyły się fiaskiem. Eskalacja przemocy spowodowała, że do dzisiaj występuje napięcie na północnej granicy kosowsko-serbskiej, a Serbowie zamieszkujacy ten obszar podejmują wszelkie działania wyrażające sprzeciw wobec jakiejkolwiek obecności instytucji Republiki Kosowa.

W dniu 2 września 2011 r. Belgrad i Prisztina porozumiały się w sprawie relacji handlowych. Strona serbska zobowiązała się uznawać kosowskie dokumenty celne, a oba państwa postanowiły znieść wzajemną blokadę importu. „Wojna celna" unaoczniła jak wielkim problemem dla społeczności międzynarodowej jest zagwarantowanie stabilności w północnym Kosowie. W ciagu ostatnich pięciu lat niepodległości Kosowa wszelkie działania mające na celu integrację północnej Mitrowicy z całością państwa kończyły się fiaskiem. Serbowie zamieszkujący znajdujące się na północy gminy Zvečan, Zubin Potok, Leposavić i Kosowska Mitrowica uznają tylko i wyłącznie zwierzchnictwo Serbii, zagwarantowane rezolucją Rady Bezpieczeństwa ONZ nr 1244 z 1999 r. W konsekwencji wszelkie instytucje reprezentujące Republikę Kosowa są tam sabotowane. Zaproponowana w lutym 2010 r. przez Międzynarodowe Biuro Cywilne (International Civilian Office, ICO) strategia integracji północy Kosowa, która miała na celu likwidację kontrolowanych przez Belgrad instytucji i zastapienie jej administracją podporządkowaną Prisztinie, nie powiodła się. Problem nie został więc rozwiązany, a północ Kosowa w pięć lat po ogłoszeniu niepodległości pozostaje poza kontrolą Prisztiny, co podważa terytorialną integralność państwa ${ }^{15}$.

O nieuznawaniu nowego państwa przez gminy na północ od rzeki Ibar świadczy nie tylko bojkot wyborów parlamentarnych w Kosowie w grudniu 2010 r., ale przede wszystkim przeprowadzone 14-15 lutego 2012 r. (w rocznicę ogłoszenia niepodległości przez Kosowo) w trzech gminach Kosowska Mitrowica, Zvečan, Zubin Potok oraz 15 lutego w gminie Leposavić referendum. W kartach do głosowania lokalne władze poprosiły o odpowiedź na pytanie czy wyborcy akceptują instytucje tzw. Republiki Kosowa. Odpowiedź od samego początku była łatwa do przewidzenia. W referendum, w którym wzięło udział około 35,5 tys. osób, aż $99 \%$ odpowiedziało negatywnie ${ }^{16}$. Szczególnym zaskoczeniem

${ }^{14}$ Kosowo. Żotnierze KFOR przejęli spalone przejście w Jarinju, 28 VII 2011, http:// wiadomosci.gazeta.pl/wiadomosci/1,114873,10024071,Kosowo_Zolnierze_KFOR_przejeli_ spalone_przejscie_w.html (dostęp 2 X 2012).

${ }_{15}$ Więcej zob. P. Sokołowska, Niepodległość jako czynnik stabilizujacy relacje serbsko-albańskie w Kosowie, „Przegląd Zachodni” 2010, nr 4, s. 156-177.

${ }^{16}$ M. Ristic, Kosovo Serb Referendum Goes Into Second Day, 15 II 2012, http://www. balkaninsight.com/en/article/kosovo-serbs-referendum-continues-through-its-second-day (dostęp 12 X 2012). 
było potępienie głosowania nie tyle przez Prisztinę, ile przede wszystkim przez Belgrad. Prezydent Serbii głosowanie na północy Kosowa uznał za działanie niezgodne $\mathrm{z}$ konstytucja, upatrując $\mathrm{w}$ nim przeszkodę na drodze do uzyskania przez Serbię statusu kandydata do UE. Starania tego kraju o to zostały zamrożone przez Brukselę w grudniu 2011 r. w związku ze wspieraniem przez Belgrad lokalnych serbskich instytucji w Kosowie. Referendum odbyło się na krótko przed kolejnym szczytem UE, na którym miała zostać podjęta decyzja w sprawie dalszej integracji Serbii ze strukturami unijnymi ${ }^{17}$.

Innym przejawem braku akceptacji państwowości Kosowa jest problem tablic rejestracyjnych. W grudniu 2010 r. kosowski rząd podją decyzję o wprowadzeniu nowych oznaczeń, zamieniając tym samym wydawane przez Misję Tymczasowej Administracji ONZ w Kosowie (UNMIK) tablice ze skrótem KS (Kosowo) na RKS (Republika Kosowa). Decyzja ta została podjęta arbitralnie, Kosowo bowiem nie ma ustalonego międzynarodowego wyróżnika kraju. Wymiana starych tablic na nowe miała odbyć się w okresie od 1 listopada $2011 \mathrm{r}$. do 1 lipca 2012 r. W odpowiedzi rząd Serbii postanowił, że od 4 stycznia 2011 r. będą wydawane dla społeczności serbskiej zamieszkującej w siedmiu gminach na terenie Kosowa nowe tablice rejestracyjne z międzynarodowym oznaczeniem SRB (Republika Serbii). Na nowych serbskich tablicach pojawiły się skróty oznaczające gminy w Kosowie, czego przykładem może być KM dla Kosowskiej Mitrowicy. W konsekwencji na terenie Kosowa pojawiły się nowe kosowskie tablice rejestracyjne RKS, stare kosowskie KS używane przez Serbów z enklaw i serbskie SRB używane przez Serbów z północy. W reakcji na te wydarzenia minister spraw wewnętrznych Kosowa Bajram Rexhepi 11 stycznia 2011 r. zakazał używania tablic RKS oraz polecił ich konfiskatę. Jednocześnie od 1 kwietnia 2012 r. Kosowska Policja została upoważniona do przeszukiwania samochodów serbskich w celu sprawdzania ich pod katem posiadania zabronionych tablic. W przypadku ich znalezienia w samochodzie dotychczasowa kara za niezarejestrowane auto zmieniła się z mandatu na konfiskatę pojazdu.

Po nieudanym wprowadzeniu strategii dla północy Kosowa kolejną próbą kosowskiego rządu było otwarcie Administracyjnego Biura ds. Północnej Mitrowicy (Mitrovica North Administrative Office, MNAO). Biuro to powstało przez wsparciu ICO, jako jeden z elementów realizacji założeń tzw. planu Ahtisaariego i koncepcji decentralizacji państwa. Do tej pory rząd Kosowa przekazywał rocznie 4 mln euro dla wsparcia obywateli w północnej Mitrowicy. Pomoc ta obejmowała wypłacanie pensji i emerytur, opłacanie rachunków funkcjonujących na tym terenie szkół, straży pożarnej, opieki społecznej, jak również pokrywanie kosztów związanych z oświetleniem ulic i oczyszczaniem miasta. Pieniądze były wypłacane $\mathrm{z}$ centralnego budżetu w Kosowie do stworzonej

${ }^{17}$ Kosowo: Serbowie przygotowuja się do referendum, 13 I 2012, http://www.rp.pl/ artykul/811642.html?print=tak\&p=0 (dostęp 12 X 2012). 
w 2001 r. Administracji UNMIK w Mitrowicy (United Nation Administration in Mitrovica, UAM) $)^{18}$. Zgodnie z ówczesną dyrektywą wydaną przez UNMIK, UAM miała takie same kompetencje jak inne gminy w całym Kosowie i pełniła funkcję swego rodzaju łącznika pomiędzy Serbami i Albańczykami w gminie Kosowska Mitrowica. Jak dotąd nie było żadnej innej instytucji, która dysponowałaby pełną legitymizacją do wypełniania tam swoich funkcji. UAM, która miała zastapić serbskie instytucje na północy ${ }^{19}$, w oczach Albańczyków uchodziła za jedną z głównych przeszkód w integracji północy z resztą Kosowa. Decyzja rządu o utworzeniu Administracyjnego Biura ds. północnej Mitrowicy i „odcięcie” UAM od finansów miało więc na celu pozbycie się administracji ONZ i pełną integrację północy z całością terytorium państwa. Utworzenie MNAO oznaczałoby wypełnienie ostatniego z zapisów planu Ahtisaariego i tym samym spełnienie warunku zamknięcia ICO nadzorującego niepodległość Kosowa, co nastapiło ostatecznie w połowie września $2012 \mathrm{r}$.

Administracyjne Biuro ds. Północnej Mitrowicy ma przyczynić się do integracji ludności z północy z instytucjami samorządowymi Kosowa oraz wesprzeć rozwój inwestycji na północ od rzeki Ibar, przede wszystkim poprzez odpowiednie zarządzanie, przydzielanie małych grantów i finansowanie projektów infrastrukturalnych. Osiemdziesięcioosobowym biurem ma kierować generalny dyrektor wykonawczy, którego kompetencje są zrównane z kompetencjami burmistrza $^{20}$. Trudna sytuacja w Kosowskiej Mitrowicy i brak akceptacji ludności serbskiej uniemożliwia działanie MNAO oraz rozciagnięcie jego funkcjonowania na cały obszar północy. W rzeczywistości ustanowienie tej instytucji nie zmieniło nic poza utworzeniem lokalnego biura, które co prawda zlokalizowane jest na północnym brzegu rzeki Ibar, jednak znajduje się w Bośniackiej Mahali (Bošnjačka Mahala), czyli na terytorium mieszanym, zamieszkiwanym przez ludność bośniacka, serbską oraz albańska, tworząca swego rodzaju bufor pomiędzy ludnością albańską i serbską na omawianym obszarze. Jakiekolwiek próby przeniesienia działań MNAO na teren innych gmin powodują ostrą reakcję ludności serbskiej, która poprzez demonstracje oraz budowanie barykad wyraża całkowity brak akceptacji dla kosowskich instytucji państwowych. Funkcjonowanie Biura utrudniane jest też zachowywaniem ze względów bezpieczeństwa w głębokiej

${ }_{18}$ Speech of the Prime Minister of the Republic of Kosovo, Hashim Thaçi at a press Conference, PM Speech MNAO opening announcement, 23 V 2012, http://www.kryeministriks.net/index.php?page=2,9,2874 (dostęp 12 X 2012).

${ }_{19}$ Note to media: SRSG Lamberto Zannier responds to the release of a briefing paper titled: „UNMIK Administration for Mitrovica” by the Office for the Coordination of the Implementation for the Strategy for the North of Kosovo, 22 IX 2010, http://www.unmikonline. org/UNMIKONLINE2009/misc/note-media-SRSG-220910.pdf (dostęp 24 IX 2012).

${ }^{20}$ Remarks of Deputy Prime Minister Petrovic, Press Conference for MNAO Establishment, $23 \mathrm{~V}$ 2012, http://www.kryeministri-ks.net/index.php?page=2,9,2874 (dostęp 12 X 2012). 
tajemnicy listy jego pracowników. Wraz z odcięciem UAM od budżetu kosowskiego skończyły się bowiem kontrakty pracownikom serbskim, którzy postanowili aplikować do pracy w MNAO ${ }^{21}$. Ujawnienie listy osób pracujących w MNAO, a w szczególności Serbów z północy, mogłoby ich narazić na szykany i inne problemy zwiąane z bezpieczeństwem. Kolejnym utrudnieniem jest ciagle niejasny podział kompetencji pomiędzy MNAO a UAM. Niewykluczone, iż dalszym działaniem będzie próba zamknięcia UAM i tym samym zlikwidowanie obecności administracji UNMIK w Mitrowicy. W tej chwili pracują tam tylko pracownicy międzynarodowi, a bez wsparcia finansowego zasadność dalszego istnienia staje pod znakiem zapytania. Otwarcie MNAO krytykowane jest też z powodu braku funkcjonalności instytucji i za to, że stało się pretekstem do rozpoczęcia dialogu politycznego z Serbią w sprawie przyszłości północnej części Kosowa.

\section{Kwestia kontroli i szczelności granic Kosowa}

Granice Kosowa ciagną się na długości 734 km, jednak władze w Prisztinie nie sprawuja nad nimi pełnej kontroli. W latach 2010-2011 odbywał się proces stopniowego przekazywania przez KFOR odpowiedzialności za ochronę granic z Albanią (marzec 2010 r.) oraz z Macedonią i Czarnogórą (styczeń-wrzesień 2011 r.) Policji Granicznej Kosowa. Obecnie KFOR, w ścisłej kooperacji z EULEX (European Union Rule of Law Mission in Kosovo) i Policją Graniczna, wciąż sprawuje kontrolę nad granica z Serbia. Zgodnie z umową z Kumanova z 1999 r. organizowane są spotkania z władzami serbskimi oraz prowadzone skoordynowane patrole graniczne z serbskimi siłami zbrojnymi w celu powstrzymania przemytu i zapobieżenia innym przestępstwom. Dodatkowo KFOR monitoruje proces rozmieszczenia wojsk według mechanizmu Joint Implementation Commission (JIC).

Policja Graniczna Kosowa powstała w 1999 r. wraz z powołaniem administracji UNMIK i jest zorganizowana na poziomie centralnym, regionalnym i lokalnym. Pracuje w niej 1337 osób personelu policji i 53 wspierających ich pracowników administracyjnych ${ }^{22}$. Inne struktury kooperujące $\mathrm{z}$ nia, to m.in. Ministerstwo Gospodarki i Finansów oraz Agencja Weterynarii i Żywności (ulokowana w biurze premiera). Na granicach Kosowa z Albania, Macedonia, Czarnogórą i Serbią działa 15 przejść granicznych, z tego 13 stałych i 2 tymczasowe. Pomimo systematycznych postępów w organizacji obsługi ruchu transgranicznego i doposażenia przejść w sprzęt do kontroli celnej, nadal widoczne

${ }^{21}$ Rozmowa z pracownikiem regionalnego Biura OBWE w Mitrowicy, 18 X 2012.

${ }^{22}$ Border Police of Republic of Kosova, Kosovo Police, http://www.kosovopolice. com/?page=2,22 (dostęp 9 IX 2012). 
Pięć lat niepodległości Kosowa. Wyzwania dla najmłodszego państwa... 567

są liczne braki. Nie wszystkie przejścia dysponują odpowiednią infrastrukturą techniczna, niezbędną do przeprowadzania kontroli celnej osób i pojazdów. Infrastrukturę niewielkich przejść lokalnych często stanowi zaledwie kilka kontenerów biurowych i socjalnych, bez należytego wyposażenia technicznego. Stałą bolączką są też kłopoty z zasilaniem w energię elektryczna, zwłaszcza w okresie zimowym ${ }^{23}$.

Granice Kosowa w zdecydowanej większości przebiegaja w obszarach wiejskich i górzystych, co utrudnia, a czasami wręcz uniemożliwia, efektywny nadzór nad nimi. Mimo że do tej pory dokonano częściowej demarkacji granicy $\mathrm{z}$ Macedonia, to tak naprawdę fizycznie nie została ona wyznaczona $\mathrm{w}$ terenie. Ponadto dość często biegnie ona przez gospodarstwa rolne lub pola uprawne. Niski poziom świadomości społecznej wśród mieszkańców żyjących w bezpośrednim sasiedztwie granicy, w sposób wyraźny utrudnia ich dyscyplinowanie w zakresie przestrzegania przepisów i nieprzekraczania linii granicznej. Należy także dodać, że prawie pięć lat po ogłoszeniu niepodległości Kosowo nadal nie przeprowadziło demarkacji granic z Albanią, Czarnogórą i Serbia.

Granica z Serbią nastręcza najwięcej trudności zarówno ze względu na nasilony ruch graniczny, jak i napięcia polityczne istniejące między sąsiadami, utrudniające rozwiązywanie bieżących problemów. Szczególnie daje się to we znaki na północy Kosowa, gdzie zbuntowane przeciwko kosowskiej władzy centralnej gminy Zubin Potok, Leposavić, Zvečan i Kosowska Mitrowica zamieszkane przez większość serbska, pozostają praktycznie poza kontrolą rządu w Prisztinie, a z pewnością poza kontrolą kosowskiej administracji celnej i Policji Granicznej. Sama granica Kosowa z Serbia, jako całość, definiowana jest przez władze serbskie jako granica prowincji lub administracyjna linia rozgraniczająca (Administrative Boundary Line). Oznacza to, że nie jest ona sensu stricto traktowana jako granica państwa z uwagi na fakt nieuznawania suwerenności Kosowa przez rząd w Belgradzie. Pomimo to serbskim eksporterom zwracany jest podatek VAT z tytułu eksportu z Serbii towarów na teren znajdujacy się po drugiej stronie wspomnianej linii ${ }^{24}$. Mając na uwadze fakt, że administracja kosowska realnie nie kontroluje tej części granicy oraz terenu Kosowa na obszarze zbuntowanych gmin, to przepływ towarów z Serbii do Kosowa na obszar tych gmin stwarza nieograniczone wręcz możliwości do nadużyć celno-podatkowych. $\mathrm{Na}$ omawianym terenie funkcjonuja wspomniane wcześniej dwa oficjalnie uznawane przez Kosowo przejścia graniczne: Gate 1 (Jarinje) i Gate 31 (Brnjak). Przejścia te mają bardzo burzliwą historię. Zostały one bowiem po ogłoszeniu niepodległości przez Kosowo w 2008 r. spalone i zdewastowane przez serbską społeczność lokalna. Ponadto oba przejścia, jak wspomniano już wcześniej, zostały zablokowanie na wiele miesięcy po próbie przejęcia kontroli nad nimi przez władze

\footnotetext{
${ }^{23}$ Rozmowa z funkcjonariuszem służby celnej misji EULEX, 9 X 2012.

${ }_{24}$ Tamże.
} 
Republiki Kosowa w lipcu 2011 r. Odpowiedź Prisztiny polegała na rozmieszczeniu tam we wrześniu tego samego roku (przy wsparciu sił KFOR i misji EULEX) funkcjonariuszy albańskich. Działania te ponownie spotkały się ze sprzeciwem, a w ramach protestu Serbowie znów zablokowali ruch na głównych drogach, wznosząc na nich barykady ${ }^{25}$. Próby ich usunięcia podejmowane przez oddziały KFOR zakończyły się starciami z ludnością serbską, w których zginęły 3 osoby, a ponad 100 zostało rannych.

Mimo zmieniających się realiów sytuacja w tym regionie nie poprawia się. Najbardziej zaawansowaną formą obecności administracji kosowskiej na obu przejściach było sprawowanie kontroli granicznej - policyjnej przez kosowska policję, przy wsparciu Policji EULEX. Wówczas kontrolę celną prowadziły jedynie siły międzynarodowe, gdyż kontrole kosowskie nie były akceptowane przez społeczność lokalną i każda próba ich podjęcia kończyła się zorganizowanym, masowanym protestem. W konsekwencji nadzór na obu przejściach faktycznie sprawują funkcjonariusze Policji i celnicy EULEX-u, a obecność dwóch przedstawicieli Kosowskiej Policji oraz jednego Kosowskiej Służby Celnej jest jedynie symboliczna i możliwa tylko dzięki transportowi lotniczemu gwarantowanemu przez EULEX. Żołnierze KFOR zapewniają bezpieczeństwo na obu przejściach oraz kontrolują nieoficjalne drogi łączące Serbię z enklawami na północy Kosowa, którymi ruch osobowy, mimo ich nieuznawania za oficjalne przejścia, odbywa się praktycznie bez żadnych ograniczeń formalnych. O skali komplikacji występujących na terenie północnej części Kosowa może świadczyć fakt, że nawet funkcjonariusze organizacji międzynarodowych maja jedynie ograniczone możliwości monitorowania i wpływania na sytuację w tym regionie, a ich swoboda przemieszczania się jest mocno ograniczona przez władze gmin północnych oraz nieformalne, zorganizowane grupy. Funkcjonariusze EULEX przemieszczają się np. w konwojach w opancerzonych pojazdach, a ataki z użyciem broni palnej lub materiałów wybuchowych na samochody i samych funkcjonariuszy na przejściach nie są odosobnione.

Brak należycie chronionych granic sprzyja przemytowi towarów i narkotyków na wielką skalę. Aby ograniczyć działania przestępczości zorganizowanej na jednym z głównych szlaków bałkańskich wiodących do UE ${ }^{26}$, Kosowo zostało w 2006 r. włączone do systemu Zintegrowanego Zarządzania Granicami (Integrated Border Management, IBM) oraz wprowadziło odpowiednie ustawy, w tym narodową strategię i plan działania $\mathrm{IBM}^{27}$. Od samego początku słabym punk-

${ }^{25}$ Kosowscy i unijni strażnicy na przejściach granicznych $z$ Serbia, 19 IX 2011, http:// wiadomosci.gazeta.pl/wiadomosci/1,114873,10298774,Kosowscy_i_unijni_straznicy_na_ przejsciach_granicznych.html (dostęp 9 IX 2012).

${ }^{26}$ Zintegrowane zarządzanie ochroną granic w Kosowie spada głównie na barki Policji Granicznej (komponentu Policji Kosowa).

${ }^{27}$ Annual Programme Border Management, Readmission and Reintegration 2011, http://ec.europa.eu/enlargement/pdf/kosovo/ipa/2011/1_rol_border_management_ 
tem ram legislacyjnych IBM był fakt, że strategia przewidywała ustanowienie najpierw instytucji, a następnie jej integrację $\mathrm{w}$ ramach struktury, natomiast ustawa o zarządzaniu granicami powinna przyczyniać się do wzmocnienia kooperacji poszczególnych podmiotów odpowiedzialnych za porządek na granicach ${ }^{28}$. Funkcjonowanie IBM jest ściśle powiązane z efektywnością Policji Granicznej Kosowa. Stoi ona w obliczu wyzwań, które obejmuja: potrzebę przejrzystego zdefiniowania struktur zarządzania, decentralizację funkcji, zwiększenie zdolności prowadzenia działań wywiadowczych (w tym zatwierdzenie zintegrowanego systemu prowadzenia operacji wywiadowczych między regionami i szczeblem centralnym kosowskiej policji), sformalizowanie więzi pomiędzy różnymi organami pracującymi na granicy oraz rozwijanie możliwości patrolowania „zielonej” granicy. Policja Graniczna Kosowa boryka się także z problemem braku wystarczajacej infrastruktury i odpowiedniego wyposażenia technicznego. Stan posiadania zależy głównie od darowizn przekazywanych przez Komisję Europejską i Międzynarodowy Program Wspomagania Szkoleń w Zakresie Ścigania Przestępczości (International Criminal Investigative Training Assistance Program, ICITAP). W odniesieniu do własnej infrastruktury informatycznej, Kosowska Policja Graniczna działa według Systemu Identyfikacji Porównania i Oceny Zagrożenia (Personal Identification Secure Comparison and Evaluation System Pisces, PISCESC), darowanego przez ICITAP, który rejestruje wszystkie przekroczenia na przejściach granicznych. W dodatku Policja Graniczna nie ma bazy danych, do której dostęp miałyby wszystkie agencje działające w ramach IBM. Ponadto kosowskie władze nie dysponuja odpowiednimi kompetencjami w sferze planowania i ponoszenia odpowiedzialności w zakresie rozwiązywania problemów wynikajacych z zarządzania struktura teleinformatyczną na granicy ${ }^{29}$. Pojawiają się również problemy związane z utrzymaniem komunikacji z posterunkami policji. Na niektórych przejściach granicznych brak jest dostępu do internetu, co mocno utrudnia wysyłanie raportów i przepływ informacji. Granice Kosowa nie są w pełni zabezpieczone odnośnie do wykrywania i prowadzenia spraw dotyczaçcych fałszowania dokumentów ${ }^{30}$.

Kolejną kwestią warunkującą ochronę i zabezpieczenie granic jest współpraca międzynarodowa. Policja Kosowa nie nawiązała jeszcze kooperacji z organizacjami i agencjami międzynarodowymi, takimi jak Interpol, Europol i Frontex, które są odpowiedzialne za zapobieganie i zwalczanie terroryzmu, handlu

readmission_and_reintegrationation_111006.pdf (dostęp 10 X 2012).

${ }^{28}$ Foreign Policy Club, NATO presence in Kosovo. Implications of KFOR troop reduction and essential political processes, Prishtina, May 2011, s. 23, http://www. fes-prishtina.org/wb/media/Publications/2011/Nato\%20Presence\%20in\%20Kosovo\%20 \%28English\%29.pdf (dostęp 20 X 2012).

${ }_{29}$ Tamze, s. 24.

${ }^{30}$ Integrated Border Management in Kosovo, Forum for Security, December 2010, s. 5, http://qkss.org/new/images/content/PDF/Integrated_border_management\%20FIQ.pdf (dostęp 12 I 2012). 
narkotykami i zorganizowanej przestępczości. W tym kontekście policjanci nie posiadaja uprawnień do zatrzymania osób poszukiwanych międzynarodowym listem gończym, chyba że wymagają tego przepisy instytucji międzynarodowych zaangażowanych w zwalczanie przestępczości i różne akty prawne. Integrację ze strukturami międzynarodowymi implikuje również fakt, że Słowacja i Cypr wciąż blokują członkostwo Kosowskiej Policji Granicznej we Frontex-ie. Mimo że Kosowo podpisało porozumienie o współpracy policji z większością państw (poza m.in. Serbia), to jednak spora część protokołów nie jest sygnowana, a przepływ informacji odbywa się bardzo wolno, co ma negatywny wpływ na ochronę granic i zwalczanie przestępczości zorganizowanej ${ }^{31}$.

Na początku grudnia $2011 \mathrm{r}$. Belgrad, po trwających prawie rok negocjacjach pod auspicjami UE, porozumiał się z Prisztiną w sprawie zintegrowanego systemu zarządzania przejściami granicznymi (IBM), natomiast 23 lutego $2012 \mathrm{r}$. odnośnie do jego protokołu technicznego ${ }^{32}$. Zgodnie z postanowieniami obydwie strony zobowiązały się do stopniowego ustanowienia wspólnych, zintegrowanych, bezpiecznych punktów na wszystkich przejściach granicznych. Urzędnicy każdej ze stron mieli otrzymać stosowny zakres obowiązków oraz wspólnie przeprowadzać kontrole. W umowie tej zagwarantowano, że na przejściach Jarinjë/Rudnice oraz Tabavije/Bërnjak, Dheu i Bardhë/Konqul, Merdare/Merdarë, Mutivodë/Mutivode i Depce/Muçibabë obecni będą też funkcjonariusze policji i służby celnej misji EULEX, działający zgodnie z zasadami zapisanymi w jej mandacie ${ }^{33}$. Postanowiono, że na przejściach granicznych nie będzie symboli państwowych Serbii i Kosowa. Specjalna grupa wdrożeniowa, składająca się z przedstawicieli Serbii, Kosowa i UE, miała nadzorować implementacje porozumienia ${ }^{34}$. Dokument ten został jednak odrzucony przez kosowskich Serbów. Zdaniem burmistrza serbskiej gminy Zubin Potok, Slavišy Risticia, podpisanie porozumienia oznaczałoby uznanie Kosowa przez Belgrad, czego Serbowie w północnym Kosowie nie mogą zaakceptować. W tej sytuacji jedynym sposobem blokowania procesu realizacji porozumienia było dalsze wzmacnianie i obrona istniejących już barykad. W kilka godzin po podpisaniu dokumentu okazało się jednak, że w samym Belgradzie istnieją różnorodne interpretacje jego postanowień. Ówczesny serbski negocjator, Borko Stefanović, podkreślał, iż wspólne zarządzanie granicą oznaczało obecność Albańczyków jako obserwatorów, bez żadnych kompetencji wykonawczych, podczas gdy Serbowie mieliby tak naprawdę tą granicą zarządzać poprzez obsadzenie jej przez policjantów

${ }^{31}$ Tamize, s. 5-6.

${ }^{32}$ Serbia porozumiała się $z$ Kosowem, 24 II 2012, http://tvp.info/informacje/swiat/ serbia-porozumiala-sie-z-kosowem/6600053 (dostęp 9 VIII 2012).

${ }^{33}$ EU facilitated dialogue: Agreement on IBM, 2 XII 2011, http://www.consilium. europa.eu/uedocs/cms_data/docs/pressdata/EN/foraff/126543.pdf (dostęp 9 VIII 2012).

${ }^{34}$ IBM Agreed Conclusions, http://www.media.srbija.gov.rs/medeng/documents/ ibm_agreed_conclusions-eng_serb.doc (dostęp 26 X 2012). 
Pięć lat niepodległości Kosowa. Wyzwania dla najmłodszego państwa... 571

i celników z Serbii ${ }^{35}$. Szybko okazało się jednak, że podpisanie porozumienia nie wiazało się z automatycznym jego wprowadzeniem w życie, Serbia bowiem nie podpisała protokołu technicznego. Szanse na jego realizację były niewielkie, przede wszystkim ze względu na kryzys polityczny w Kosowie oraz wybory w Serbii i - w efekcie - przejęcie władzy przez prawicowy rząd latem $2012 \mathrm{r}$.

Dopiero we wrześniu $2012 \mathrm{r}$. Belgrad poinformował UE, że jest gotowy do wdrożenia kosowsko-serbskiego porozumienia o wspólnym zarządzaniu granica, a w szczególności jego protokołu technicznego. Nowy przedstawiciel Serbii Dejan Pavićević, oddelegowany do prowadzenia rozmów na poziomie technicznym, zwracał jednak uwagę na szereg kwestii, które nie zostały uregulowane w protokole technicznym (26 września 2012 r.). Zdaniem Pavićevicia dokument ten nie był korzystny dla Serbii, czego dowodzi fakt obecności na posterunkach kosowskich celników. Według niego powinien on określać jedynie techniczne aspekty dalszej kontroli linii administracyjnej pomiędzy Serbią a Kosowem. Ponadto wykonawcza rola EULEX, o której mowa w uzgodnionym porozumieniu, jest określona bardzo niejednoznacznie, szczególnie jeśli chodzi o zakres kompetencji na północnych przejściach Kosowa. Wszystkie należności celne powinny być egzekwowane przez EULEX w zgodzie z jej mandatem wykonawczym, a nie przez celników kosowskich. Pavićević zaznaczył, że niektóre postanowienia mogą być korzystniejsze na poziomie tzw. grup wdrożeniowych, które składać się będą z przedstawicieli Serbii, Kosowa i UE ${ }^{36}$. Może to oznaczać, że intencją władz Serbii będzie zmiana postanowień na poziomie grup roboczych i wycofanie się z implementacji dokumentów ustalonych przez wcześniejszy rząd.

\section{Kosowska Służba Celna a zwalczanie przestępczości zorganizowanej w Kosowie}

W dniu 12 grudnia 2008 r. funkcjonująca od sierpnia 1999 r. Służba Celna $\mathrm{UNMIK}^{37}$ została przemianowana na Służbę Celną Kosowa. Wcześniej, w dniu 11 listopada $2008 \mathrm{r}$. Zgromadzenie Kosowa przyjęło nowy kodeks celny, uważany za dokument zgodny z normami prawnymi UE. Wprowadzenie go w życie miało przyczynić się do rozwoju gospodarki kosowskiej. Działalność administracji celnej, poza aspektami ekonomicznymi, takimi jak pobór ceł i podatków związanych

${ }_{35}$ Kosovo-Serben lehnen Grenzabkommen ab, 3 XI 2012, http://www.stern.de/politik/ ausland/kosovo-serben-lehnen-grenzabkommen-ab-1758459.html (dostęp 2 I 2012).

${ }^{36}$ Kosovo customs officers trouble, EULEX role unclear, 22 IX 2012, http://www. tanjug.rs/news/60100/kosovo-customs-officers-trouble-eulex-role-unclear.htm (dostęp $1 \mathrm{X} 2012)$.

37 Głównym celem Służby Celnej UNMIK, funkcjonującej w ramach filaru UE, było zapewnienie stosowania sprawiedliwych i jednolitych przepisów celnych oraz innych przepisów, mających zastosowanie do towarów, które podlegają dozorowi celnemu. 
z importem towarów, prezentuje analogicznie jak w innych krajach, niemniej istotny aspekt pozaekonomiczny, czyli egzekwowanie pozaekonomicznych ograniczeń obrotu towarowego z zagranica, w szczególności tych mających znaczenie dla życia i zdrowia ludzi, zwierząt i roślin, ale także związanych z ochroną prawa i porządku publicznego. Kosowska Służba Celna odgrywa istotną rolę przy wdrażaniu porozumień w zakresie bezpieczeństwa oraz zwalczania przestępczości zorganizowanej i wszelkiego rodzaju przemytu, podpisanych w ramach IBM. Mimo problemów związanych z wciąż kształtującą się niepodległością państwa, rozwiniętą przestępczością graniczną, demarkacją granic i ograniczeniami inwestycyjnymi, z postawionych przed nią zadań wywiązuje się coraz lepiej, choć nadal daleka jest od ideału. Dochody z ceł stanowią około 70\% budżetu Kosowa. Personel celny jest złożony głównie z Albańczyków, około 20\% miejsc przeznaczonych jest jednak dla przedstawicieli mniejszości narodowych.

Służba Celna Kosowa składa się z dwóch części zajmujących się odpowiednio kwestiami gospodarczymi i bezpieczeństwa. W zakresie gospodarczym do jej zadań należą:

- pozyskiwanie środków z działalności celnej, takich jak cła, podatek od wartości dodanej, akcyza na rzecz skonsolidowanego budżetu Kosowa;

- kontrola importu i eksportu, obrona gospodarki, ochrona znaków towarowych i inne;

- statystyka handlu, czyli kontrola obrotu towarowego.

Natomiast w zakresie bezpieczeństwa zajmuje się ona:

- walką z nielegalną działalnościa;

- zwiększeniem bezpieczeństwa poprzez zwalczanie przestępczości transgranicznej, przemytu narkotyków itp.;

- ochroną ludności i środowiska, zapobieganiem przemytowi broni i substancji wybuchowych ${ }^{38}$.

Efektywność kosowskiej administracji celnej pozostawia dużo do życzenia, na co ma wpływ skomplikowana sytuacja polityczna zarówno zewnętrzna, jak i wewnętrzna. Utrudnia to realizację ustawowych zadan i sprawowanie pełnej kontroli granic i przejść granicznych. Nierozwiązana kwestia terytorialnej integralności kraju z jego północą stanowi olbrzymi problem dla służby celnej i jednocześnie bodziec dla różnych nadużyć. Brak inwestycji w administrację celną i jej infrastrukturę, zły stan środków transportu, utrudniający zakładanie składów celnych i egzekwowania nienaruszalności tak zabezpieczonego towaru, jak również rozpoznawanie ingerencji w konstrukcję pojazdu (np. w celu ukrycia przemycanych dóbr), trudności w funkcjonowaniu systemu gwarancyjnego, związane m.in. z niemożnością uzyskania członkostwa w organizacjach międzynarodowych systemów gwarancyjnych (np. TIR, ATA), to kolejne problemy negatywnie wpływające na efektywność pracy kosowskiej służby celnej. Do tego

${ }^{38}$ Kosovo Customs, http://dogana.rks-gov.net/en/Mission (dostęp 11 X 2012). 
Pięć lat niepodległości Kosowa. Wyzwania dla najmłodszego państwa... 573

dochodzi kwestia skuteczności w egzekwowaniu prawa i utrzymujący się wysoki poziom przestępczości w kraju, w tym trudny do zdefiniowania stan najwyższej kadry zarządzającej administracją

\section{Kosowskie Siły Bezpieczeństwa a suwerenność państwa}

Wyrazem dyskusyjnej suwerenności Kosowa jest brak własnych, w pełni podległych rządowi i kontrolowanych przezeń sił zbrojnych. To właśnie one stanowia jeden z filarów, na którym opiera się państwowość i funkcjonalność kraju. Tymczasem wraz z akceptacja planu Ahtisaariego oraz ogłoszeniem niepodległości, Kosowo formalnie zostało ich pozbawione. Jedyną formacją realizująca w pewnej części ich zadania stały się Siły Bezpieczeństwa Kosowa (Kosovo Security Force, KSF). Żadne z dokumentów dotyczacych KSF nie dają im jednak prawa ochrony i obrony terytorium, przestrzeni powietrznej, krajowej infrastruktury krytycznej czy też interesów narodowych. Warto również zauważyć, że poza policja w Kosowie nie funkcjonuje żadna formacja odpowiedzialna za ochronę porządku publicznego.

Proces tworzenia KSF rozpoczą się w połowie 2008 r., gdy parlament Republiki Kosowa przyjął ustawę o rozwiązaniu w ciagu roku stworzonego przez UNMIK w 1999 r. Korpusu Ochrony Kosowa ${ }^{40}$ (Kosovo Protection Corps, KPC ${ }^{41}$. Demobilizacja KPC odbywała się pod nadzorem Międzynarodowych Sił Wojskowych (International Military Presence), których funkcje realizowały siły NATO - KFOR. Zgodnie z art. 5 ustawy o służbie w KSF członkowie Korpusu Ochrony Kosowa mogli ubiegać się o służbę w KSF przy założeniu, że nie będą mieć specjalnych przywilejów oraz że nie będą nosić insygniów innych niż Sił Bezpieczeństwa Kosowa ${ }^{42}$. Istota formowania nowej struktury było jednakże wykluczenie automatycznego przekształcenia KPC w KSF, a tę ostatnią postanowiono stworzyć od podstaw.

Zgodnie z założeniami planu Ahtisaariego, KSF miały stać się organem reagowania kryzysowego o kompetencjach prowadzenia operacji w Kosowie i za granica, ale jedynie w zakresie poszukiwań i ratownictwa, neutralizowania substancji wybuchowych, niszczenia amunicji, pełnienia funkcji straży pożarnej oraz unieszkodliwiania niebezpiecznych materiałów. Ich misją jest też wspieranie rządu Republiki Kosowa w celu zapewnienia bezpieczeństwa narodowego.

${ }^{39}$ Rozmowa z funkcjonariuszem służby celnej misji EULEX, 9 X 2012.

${ }^{40}$ Więcej zob.: P. Sokołowska, Polityka zagraniczna i bezpieczeństwa RFN wobec państw obszaru bytej Jugosławii w latach 1990-2005, Toruń 2010, s. 222-230.

${ }^{41}$ Law No.03/L-083 on Dissolution of the Kosovo Protection Corps, 13 VI 2008, http:// www.kuvendikosoves.org/common/docs/ligjet/2008_03-L083_en.pdf (dostęp 20 X 2012).

${ }^{42}$ Tamize. 
Moga służyć jako krajowe siły bezpieczeństwa w państwie, chronić obywateli i zostać wysłane za granicę zgodnie z międzynarodowymi porozumieniami. Siły te są uprawnione do noszenia broni lekkiej i mają składać się z 2,5 tys. aktywnych żołnierzy i 800 rezerwistów w wieku 19-35 lat. Nie przyznano im natomiast prawa do posiadania broni ciężkiej, takiej jak czołgi i artyleria, oraz zdolności prowadzenia ofensywnych operacji powietrznych ${ }^{43}$. Zwierzchnikiem Sił Bezpieczeństwa Kosowa jest prezydent, który na wniosek rządu mianuje ich dowódcę $e^{44}$. Wszelkie zmiany dotyczące funkcjonowania Sił Bezpieczeństwa miały być ustalane przez KFOR we współpracy z Międzynarodowym Przedstawicielem Cywilnym $^{45}$. Pierwszy przegląd zdolności operacyjnych KSF zaplanowano nie wcześniej niż pięć lat od daty wejścia w życie ustawy o Siłach Bezpieczeństwa Kosowa ${ }^{46}$, tj. w 2013 r.

Proces formowania Sił Bezpieczeństwa Kosowa odbywał się przy ścisłej konsultacji z KFOR, który otrzymał zadanie doprowadzenia do ich pełnej funkcjonalności operacyjnej. Realizację tego zadania NATO podjęło 12 czerwca 2008 r., rozpoczynając tym samym proces planowania i rozwoju KSF oraz tworzenia cywilnych struktur nadzorujących. Siły KSF szkolone były zgodnie ze standardami NATO i poddane demokratycznej kontroli cywilnej ${ }^{47}$. Dodatkowo KFOR, wraz z rządem Kosowa, odpowiadał za stworzenie podłoża formalno-prawnego, koniecznego do przeprowadzenia weryfikacji i naboru. Sojusz Północnoatlantycki wspomagał również ustanowienie Ministerstwa ds. Sił Bezpieczeństwa poprzez powołanie Zespołu Doradczego NATO.

Powstałe dzięki pomocy NATO Ministerstwo ds. Sił Bezpieczeństwa, odpowiedzialne jest za sprawowanie kontroli cywilnej nad Siłami Bezpieczeństwa Kosowa, w tym za zarządzanie i administrację. W jego skład wchodzi personel cywilny oraz mundurowy. Ministerstwo odpowiada poprzez Prezesa Rady Ministrów przed parlamentem Kosowa. Misją Ministerstwa, które stanowi również najwyższy poziom dowódczy KSF, jest opracowywanie, wdrażanie, ocena i rozwój polityki i działań KSF zgodnie z konstytucją i ustawami Republiki Kosowa ${ }^{48}$.

${ }^{43}$ Kosovo Security Force: Mission Statement, Ministry for the Kosovo Security Forces, http://mksf-ks.org/?page=2,7 (dostęp 13 X 2012).

${ }^{44}$ Constitution of the Republic of Kosovo, art. 126, http://www.kushtetutakosoves. info/repository/docs/Constitution.of.the.Republic.of.Kosovo.pdf (dostęp 23 X 2012).

${ }^{45}$ Międzynarodowy Przedstawiciel Cywilny zakończył swoją misję w Kosowie w połowie września 2012 r., wraz z zamknięciem ICO.

${ }^{46}$ Law No. 03/L-082 on Service in the Kosovo Security Force, 13 VI 2008, http://mksfks.org/repository/docs/Law\%20on\%20Service\%20in\%20the\%20KSF.pdf (dostęp 20 X 2012).

${ }^{47}$ Kosovo Force 2010, s. 10-11, http://www.nato.int/kfor/docu/about/brochure/ brochure.pdf (dostęp 10 X 2012).

${ }^{48}$ Ministry for the Kosovo Security Force: Mission Statement, http://www.mksf-ks. org/?page=2,7 (dostęp 10 X 2012). 
Pięć lat niepodległości Kosowa. Wyzwania dla najmłodszego państwa... 575

Przed podjęciem przez Siły Bezpieczeństwa Kosowa oficjalnej służby, 21 stycznia 2009 r. ${ }^{49}$ przeprowadzony został, przy wsparciu KFOR, proces weryfikacji kandydatów, a w szczególności około 1,4 tys. byłych członków KPC ${ }^{50}$. Proces ten napotykał jednak szereg problemów. Jednym z nich było tymczasowe zawieszenie wsparcia i szkolenia przez KFOR w związu z obecnością członków KSF podczas uroczystości upamiętniającej Armię Wyzwolenia Kosowa (UÇK), która odbyła się 5 marca 2010 r. Członkowie KSF w jej trakcie nie tylko prezentowali broń, lecz wystapili pod flaga NATO. Było to sprzeczne z ustawą o KSF, która określa status tych sił oraz całkowicie niezgodne z doktryną KFOR, silnie akcentująca apolityczność i bezstronność. Innym przykładem ilustrującym skomplikowaną sytuację wewnątrz KSF było wydalenie ze służby (począwszy od 2010 r.) kilkuset członków KSF ze względu na wcześniejsze zaangażowanie w działania wspomnianej UÇK (mimo iż początkowo pozytywnie przeszli weryfikację) ${ }^{51}$.

Siły Bezpieczeństwa Kosowa mają nie tylko ograniczone prawem możliwości, ale borykają się też z szeregiem trudności związanych z uzyskaniem pełnej funkcjonalności. Chociaż oficjalnie pozostają pod konstytucyjną kontrolą władz Kosowa, to jednak NATO nadal sprawuje nadzór nad prowadzonymi przez nie operacjami. Decyzję w kwestii zaprzestania kontroli może podjać Rada Północnoatlantycka. Dowództwo KFOR w listopadzie 2011 r. wysłało do NATO raport o osiagnięciu przez KSF pełnej operacyjności, jednak Rada nie może podjąć takiej decyzji, ponieważ 4 z 28 państw członkowskich nie uznają niepodległości Kosowa ${ }^{52}$.

\section{Podsumowanie}

Bilans pięciu lat niepodległości Kosowa wspieranego przez społeczność międzynarodową nie wygląda imponująco. Instytucje państwowe po zakończeniu tzw. niepodległości kontrolowanej wykazują same deficyty. $\mathrm{O}$ tym, jak trudne jest wsparcie reform w Kosowie wspomina też Europejski Trybunał Obrachunkowy w raporcie z 30 października 2012 r. Zgodnie z jego treścią w państwie tym, jako

${ }^{49}$ Kosovo's security force launched, 21 I 2009, http://news.bbc.co.uk/2/hi/europe/ 7841789.stm (dostęp 12 X 2012).

${ }^{50}$ S. Selimi, KSF - A Professional Force with NATO Standards, [w:] Stand up, Challenges and Success, http://www.mksf-ks.org/repository/docs/Broshura\%20 ANGLISHT\%20\%20-\%20finale\%207.02.2011.PDF (dostęp 10 X 2012).

${ }^{51}$ Cleansing in KSF, 16 II 2010, http://www.emg.rs/en/news/serbia/113623.html (dostęp 25 X 2010).

${ }^{52}$ Media Monitoring Headlines 23.10.2012, UNMIK Division of Public Information, http://www.unmikonline.org/Pages/MediaMonitoring.aspx (dostęp 25 X 2012). 
największym na świecie beneficjencie pomocy finansowej UE (w przeliczeniu na mieszkańca), nie udało się osiagnąć sukcesów w zakresie praworządności. Mimo że widoczne są pewne postępy w działaniach służby celnej, to jednak pomoc dla policji i sądownictwa przyniosła jedynie umiarkowane powodzenie. Ponadto niestabilny system polityczny, brak efektywnie funkcjonujących instytucji państwowych, korupcja i przestępczość zorganizowana, naciski polityczne na wymiar sprawiedliwości, brak przejrzystości i egzekwowania prawa to kolejne, istotne problemy, z którymi boryka się niepodległe Kosowo. Niewydolność Policji oraz Policji Granicznej negatywnie wpływa na porządek i bezpieczeństwo państwa. Siły Bezpieczeństwa Kosowa pozostają ciagle na etapie naboru i szkoleń, nie mając statusu sił zbrojnych. I mimo iż władze Kosowa dążą do tego, aby w 2013 r. KSF taki status uzyskały, to jest to raczej mało prawdopodobne. Uwzględniając fakt, że sytuacja na północy jest nadal niestabilna oraz biorąc pod uwagę odroczenie (w październiku 2012 r.) decyzji Sojuszu Północnoatlantyckiego w sprawie zmniejszenia liczby stacjonujących tam jednostek KFOR, nie wydaje się, aby w $2013 \mathrm{r}$. doszło do zmiany zadań KSF i zniesienia kontroli międzynarodowej tych sił.

Sytuacja na północy jest skomplikowana i pozostaje poza kontrola Prisztiny. Nawet jeśli Serbowie z północy zostaną włączeni do dialogu politycznego pomiędzy Belgradem a Prisztina, to skuteczne rozwiązanie tego problemu jest mało prawdopodobne, co będzie skutkowało dalszym zamrożeniem konfliktu w regionie. Ludność serbska na północy nadal będzie sprzeciwiać się jakiejkolwiek obecności instytucji Republiki Kosowa oraz porozumieniom podpisanym w ramach zakończonego dialogu technicznego. O skali niezadowolenia już dziś świadczą barykady, a także liczne protesty organizowane na północy Kosowa przeciwko realizacji porozumienia dotyczacego Zintegrowanego Systemu Zarządzania Granicami. Serbowie na północy w przeciwieństwie do Serbów z południa będą więc wykorzystywać wszelkie środki do walki przeciwko implementacji podpisanych umów, bojkotując zarówno działalność MNAO, jak i przejazd przez położone na północy przejścia Jarinje i Brnjak, gdzie obecni mają być przedstawiciele Służby Celnej i Policji Kosowa. Tym samym będą dalej korzystać z tras alternatywnych i robić wszystko, aby utrzymać integralność terytorialną i ciagłość państwową z Serbią. 